\title{
PENGARUH PERANAN PROMOSI MEDIA SOSIAL INSTAGRAM (BANBAN.TEA) TERHADAP KEPUTUSAN PEMBELIAN KONSUMEN DI BAN BAN TEA EMPORIUM PLUIT MALL
}

\section{The Effect of the Role of Instagram Social Media Promotion (Banban.Tea) On Consumer Purchase Decisions in Ban Ban Tea Emporium Pluit Mall}

\author{
Oktaviani Putri Alexander ${ }^{1)}$, Johannes Kurniawan ${ }^{2)}$ \\ ${ }^{1)}$ Strata Satu Hospitaliti dan Pairiwsata, Universitas Bunda Mulia \\ ${ }^{2)}$ Diploma Tiga Perhotelan, Akademi Pariwisata Bunda Mulia
}

Diterima Tanggal 10 Oktober 2020 Disetujui 20 November 2020

\begin{abstract}
The development that is happening in the business world today has greatly benefited from the presence of Instagram social media, especially in the world of food \& beverages and has increased from time to time. This study aims to determine the effect of the role of Instagram promotion (banban.tea) on purchasing decisions at ban ban tea emporium pluit mall. This study uses a quantitative causal research method with questionnaire data collection techniques using purposive sampling and has a total number of respondents as many as 100 respondents and data processing using SPSS (Statistical Packages for Social Sciences) version 24. And using research methods validity test, reliability test, classical assumption test. (normality test, heteroscedasticity test), simple linear regression analysis, $T$ test, $F$ test, coefficient of determination. The results of this study note that the $T$ test shows that the variable $X$ (promotion) has a partially significant effect on the variable $Y$ (purchase decision), the $F$ test is to determine whether the independent variable affects the dependent variable, and the last is the coefficient of determination test which states that the variable $X$ (promotion) on variable Y (buying decision) has an effect of $69.1 \%$, while the remaining $30.9 \%$ is influenced by other variables that the researcher is not careful about. Based on the results of the research test, it can be concluded that the promotion of social media Instagram (banban.tea) has a significant effect on purchasing decisions. Suggestions that can be given in this study to Instagram account owners (banban.tea) in order to maintain and create new innovations so that consumers will make repeat purchases.
\end{abstract}

Keywords: Promotion, Purchase Decision, Ban ban Tea Emporium Pluit Mall.

Perkembangan yang terjadi di dunia bisnis saat ini sangat diuntungkan dengan adanya kehadiran sosial media instagram khususnya di dunia food\& beverages dan telah meningkat dari waktu ke waktu. Penelitian ini bertujuan untuk mengetahui pengaruh peranan promosi instagram (banban.tea) terhadap keputusan pembelian di ban ban tea emporium pluit mall. Penelitian ini menggunakan metode penelitian kuantitatif kausal dengan teknik pengumpulan data kuesioner menggunakan purposive sampling dan memiliki jumlah responden sebanyak 100 responden dan pengolahan datanya menggunakan SPSS (Statistical Packages For Social Sciences) versi 24. Dan menggunakan metode penelitian uji validitas, uji realibilitas, uji asumsi klasik (uji normalitas, uji heteroskedastistas), analisis regresi linear sederhana, uji T, Uji F, koefisien determinasi. Hasil dari penelitian ini diketahui bahwa Uji T menunjukkan bahwa variabel X (promosi) berpengaruh signifikan secara parsial terhadap variabel Y (keputusan pembelian), Uji F untuk mengetahui apakah variabel bebas berpengaruh terhadap variabel terikat, dan yang terakhir adalah uji koefisien determinasi yang menyatakan bahwa variabel X (promosi) terhadap variabel Y (keputusan pembellian) berpengaruh sebesar 69,1\% sedangkan sisanya sebesar 30,9\% dipengaruhi oleh variabel lain yang peneliti tidak teliti. Berdasarkan hasil uji penelitian dapat disimpulkan bahwa promosi media sosial instagram (banban.tea) berpengaruh secara signifikan terhadap keputusan pembelian. Saran yang dapat diberikan dalam penelitian ini kepada pemilik akun instagram(banban.tea) agar dapat mempertahankan dan membuat inovasi yang baru sehingga konsumen akan melakukan pembelian ulang.

Kata Kunci : Promosi, Keputusan Pembelian, Ban Ban Tea Emporium Pluit Mall.

\section{Pendahuluan}

\subsection{Latar Belakang}

Media sosial dalam era digital mengalami perkembangan yang sangat pesat bahkan telah menjadi bagian dari gaya hidup masyarakat.
Teknologi yang terus berkembang diimbangi dengan kemudahan akses komunikasi dan informasi yang menjadikan media sosial sebagai platform atau sarana yang paling banyak digunakan. Salah satunya adalah 
Instagram, media sosial ini tak terlepas dari kehidupan dan aktivitas sehari-hari masyarakat. Ditambah lagi, Instagram adalah media sosial yang dapat diakses oleh berbagai kalangan masyarakat tanpa persyaratan berbayar dan penggunanya dapat dengan mudah untuk berbagi informasi dengan mengunggah konten dalam bentuk foto, video, snapgram dan juga dapat digunakan sebagai wadah seseorang untuk berbisnis. Pasar bisnis di Indonesia saat ini sangat diuntungkan dengan adanya kehadiran promosi media sosial instagram. Akan tetapi tidak dapat dipungkiri lagi bahwa dengan meningkatnya hal tersebut akan membuat banyak persaingan di instagram. Dengan adanya teknologi informasi yang semakin mulai berkembang seperti instagram telah mempengaruhi berbagai macam aspek kehidupan masyarakat, contohnya dari cara berpikir seseorang, dan cara berperilaku seseorang. berdasarkan laporan dari datareportal.com mengatakan bahwa pada Januari 2020 di Indonesia berada sekitar 160 juta pengguna media sosial.

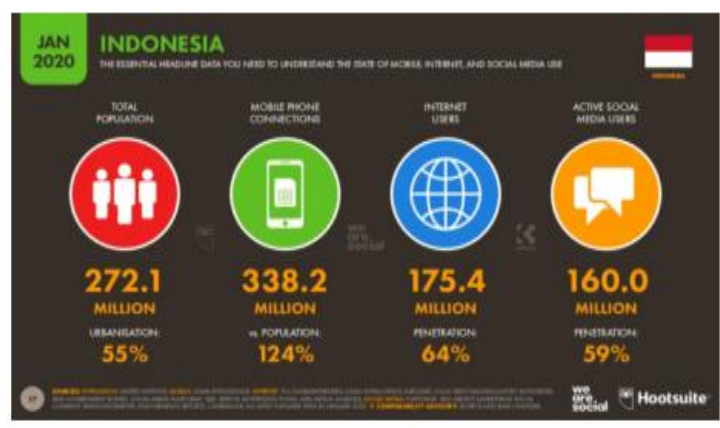

\section{Gambar 1. Jumlah Pengguna Internet di Indonesia tahun 2020}

Sumber:

(https://datareportal.com/reports/digital-2020global-digital-overview, 2020)

Dari gambar 1 yang ada diatas menunjukkan bahwa penggunaan internet di Indonesia cukup tinggi. Pada januari 2020 dengan persentase sebesar 55\% atau 272,1 juta populasi di Indonesia, lalu sebesar $124 \%$ atau sekitar 338,2 juta orang merupakan pengguna handphone, lalu sebesar 64\% atau sekitar 175,4 juta orang merupakan pengguna aktif internet dan 59\% atau sekitar 160 juta orang merupakan pengguna aktif media sosial.

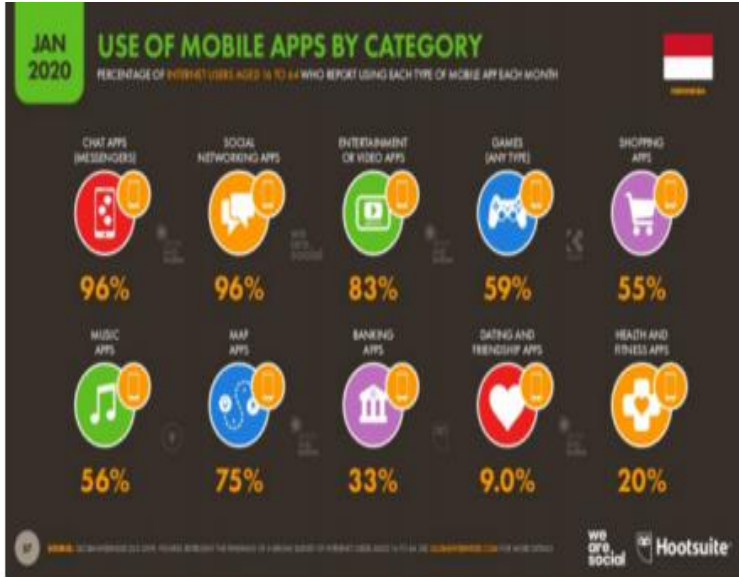

Gambar 2. aplikasi yang sering digunakan di Indonesia Sumber:

(https://datareportal.com/reports/digital-2020global-digital-overview, 2020)

Dari gambar 2 yang ada diatas menunjukkan bahwa aplikasi yang paling sering digunakan oleh orang-orang Indonesia adalah aplikasi jejaring sosial dengan persentase sebesar 96\%. Dan media sosial instagram merupakan bagian dari aplikasi jejaring sosial (social networking apps). Dengan kemajuan teknologi yang berkembang secara cepat dan pesat, seringkali teknologi dianggap mengambil alih kehidupan manusia. Diperkirakan dalam waktu penuh sehari 24 jam, masyarakat tidak dapat lepas dari keberadaan teknologi, mulai dari sebagai sarana untuk mencari informasi secara jelas, bersosialisasi atau bahkan sebagai wadah untuk menjalankan bisnis. Tentunya hal tersebut membawa dampak langsung bagi kehidupan manusia baik secara positif maupun negatif.

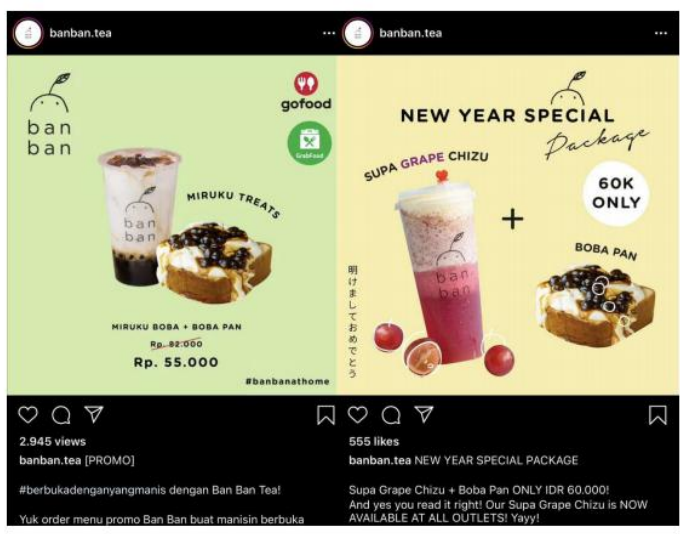

Gambar 3. Bentuk Promosi akun instagram (banban.tea) Sumber: (https://www.instagram.com/banban.tea/?hl=en) 
Ban ban tea hanya menggunakan media sosial instagram sebagai sarana promosi untuk menarik customer dengan menggugah foto atau video yang sifatnya informatif sehingga orang-orang menjadi tertarik dengan produk ban ban tea. Setelah tertarik maka akan ada keputusan pembelian konsumen yang terjadi setelah melihat promosi yang dilakukan oleh banban di media sosial instagram.

\section{Promosi}

Promosi adalah untuk mempengaruhi konsumen dalam mengambil keputusan untuk meningkatkan penjualan, Dalam promosi tidak hanya sekedar berkomunikasi ataupun menyampaikan informasi, tetapi juga menginginkan komunikasi yang mampu menciptakan suasana atau keadaan dimana para pelanggan bersedia memilih dan memiliki. Dengan demikian promosi yang akan dilakukan haruslah selalu berdasarkan atas beberapa hal sehingga tujuan yang diharapkan dapat tercapai. Menurut Tjiptono (2015:387), pada umumnya kegiatan promosi harus berdasarkan pada tujuan sebagai berikut:

- Menginformasikan

Kegiatan promosi yang bertujuan untuk berusaha menginformasikan kepada konsumen akan merek atau produk perusahaan baik itu produk baru ataupun merek baru maupun produk dan merek yang sudah lama, tetapi belum luas terdengar oleh konsumen. Atau secara sederhana kegiatan ini adalah untuk memberitahukan konsumen tentang produk perusahaan. Promosi ini dilakukan untuk memberi informasi kepada konsumen tentang produk yang dihasilkan perusahaan.

- Membujuk

Kegiatan promosi yang bersifat membujuk dan mendorong konsumen untuk melakukan pembelian atas produk yang ditawarkan. Perusahaan lebih mengutamakan penciptaan kesan positif kepada konsumen agar promosi dapat berpengaruh terhadap perilaku pembeli dalam waktu yang lama.

- Mengingatkan

Kegiatan promosi yang bersifat mengingatkan ini dilakukan untuk mempertahankan merek produk di hati masyarakat, dan mempertahankan pembeli yang akan melakukan transaksi pembelian secara terusmenerus.

\section{Keputusan Pembelian}

Keputusan pembelian tidak terpisahkan dari bagaimana sifat seorang konsumen (consumer behavior) sehingga masing-masing konsumen memiliki kebiasaan yang berbeda dalam melakukan pembelian, Kotler \& Armstrong (2016:188) mengemukakan keputusan pembelian memiliki indikator sebagai berikut:

- Pilihan Produk

Konsumen dapat mengambil keputusan untuk membeli sebuah produk atau menggunakan uangnya untuk tujuan yang lain. Dalam hal ini perusahaan harus memusatkan perhatiannya kepada orang-orang yang berminat untuk membeli sebuah produk yang mereka tawarkan.

- Pilihan Merek

Konsumen harus mengambil keputusan tentang merek nama yang akan dibeli setiap merek memiliki perbedaan tersendiri. Dalam hal ini perusahaan harus mengetahui bagaimana konsumen memilih sebuah merek.

- Pilihan Penyalur Konsumen harus mengambil keputusan tentang penyalur mana yang akan dikunjungi. Setiap konsumen berbedabeda dalam hal menentukan penyalur bisa dikarenakan faktor lokasi yang dekat, harga yang murah, persediaan barang yang lengkap, kenyamanan dalam belanja, keluasan tempat dan lain- lain.

- Waktu Pembelian

Keputusan konsumen dalam pemilihan waktu pembelian bisa berbeda-beda misalnya ada yang membeli setiap hari, satu minggu sekali, dua minggu sekali dan lain sebagainya.

- Jumlah Pembelian

Konsumen dapat mengambil keputusan tentang seberapa banyak produk yang akan dibelanjakan pada suatu saat. Pembelian yang dilakukan mungkin lebih dari satu. Dalam hal ini perusahaan harus mempersiapkan 
banyaknya produk sesuai dengan keinginan yang berbeda-beda.

\section{Social Media}

Media sosial adalah sekelompok aplikasi berbasis internet yang dibangun atas dasar ideologis dan teknologi web 2.0, yang memungkinkan terjadi penciptaan dan pertukaran yang dihasilkan dari pengguna konten (Kaplan dan Haenlein, 2010). Sedangkan menurut Kotler dan Keller (2012), media sosial merupakan sarana bagi konsumen untuk berbagi teks, gambar, audio, dan video informasi satu sama lain dengan perusahaan dan sebaliknya. Menurutnya, jenis media sosial terbagi menjadi 3 yaitu (1) Online communities and forums yang dibentuk oleh sekelompok konsumen tanpa adanya pengaruh iklan dan afiliasi perusahaan di mana anggota yang tergabung dapat berkomunikasi dengan perusahaan dan satu anggota dengan anggota lainnya melalui posting, instant messaging, dan chat. (2) Blog yang merupakan catatan jurnal online yang diperbaharui secara berkala dan merupakan saluran yang penting bagi Word of Mouth. (3)Social networks dapat berupa situs jejaring sosial seperti Facebook, MySpace, Linkedln, dan Twitter.

Melihat suksesnya ban ban tea peneliti tertarik melakukan penelitian tentang bagaimana ban ban menggunakan platform peranan media sosial instagram untuk mempromosikan makanan atau minuman yang dijualnya sehingga terjadinya keputusan pembelian konsumen.

\subsection{Identifikasi Masalah}

Dari latar belakang masalah yang diuraikan, dapat dikemukakan identifikasi-identifikasi masalah sebagai berikut:

1. Jumlah Follower akun instagram (banban.tea) lebih unggul dibandingkan akun instagram lainnya. Hal ini menandakan bahwa adanya kemungkinan bagi ban ban tea untuk meraih jumlah pembeli yang lebih banyak dibandingkan produk lainnya. Selain itu banyak produk yang serupa dengan ban ban tea sudah mulai gencar dalam melakukan promosi melalui media sosial salah satunya instagram.
2. Instagram menjadi perantara hubungan antara penjual dengan pembeli dalam mempengaruhi keputusan pembelian melalui unggahan yang diunggah di akun instagram (banban.tea).

\subsection{Tujuan dan Manfaat Penelitian}

Dalam sebuah penelitian bahkan di setiap penelitian pastinya harus memiliki tujuan penelitian. Tujuan penelitian ini adalah untuk mengetahui pengaruh peranan promosi media sosial instagram (banban.tea) terhadap keputusan pembelian konsumen di ban ban tea Emporium Pluit Mall.

\section{Metode Penelitian}

\subsection{Metode}

Subjek penelitian menurut Suharsimi Arikunto (2016) memberi batasan subjek penelitian sebagai benda, hal atau orang tempat data untuk variabel penelitian melekat, dan yang di permasalahkan. Berdasarkan pengertian tersebut maka subjek dalam penelitian ini adalah pelanggan yang sudah pernah membeli produk di ban ban tea Emporium Pluit Mall.

Objek penelitian menurut Sugiyono (2017) objek penelitian adalah sasaran ilmiah untuk mendapatkan data dengan tujuan dan kegunaan tertentu tentang sesuatu hal objektif, valid dan reliabel tentang suatu hal (variabel tertentu). Berdasarkan pengertian tersebut maka objek dari penelitian ini adalah pengaruh peranan promosi media sosial terhadap keputusan pembelian konsumen di ban ban tea Emporium Pluit Mall.

\subsection{Populasi dan Sampel Penelitian}

Menurut Sugiyono (2017) Populasi adalah wilayah generalisasi yang terdiri dari objek atau subjek yang mempunyai kuantitas dan karakteristik tertentu yang ditetapkan oleh untuk di pelajari dan kemudian di Tarik kesimpulannya. Berdasarkan pernyataan di atas, peneliti menyimpulkan bahwa populasi dalam penelitian ini yang dapat digunakan untuk menentukan sampel adalah para pengguna aktif media sosial instagram yang merupakan pengikut (follower) akun instagram (banban.tea). Dimana objek dalam penelitian adalah akun instagram(banban.tea) sebanyak 42.400 pengikut.

Menurut Sugiyono (2017) sampel adalah bagian dari jumlah dari karakteristik yang 
dimiliki oleh populasi tersebut. Bila populasi besar, dan peneliti tidak mungkin mempelajari semua yang ada pada populasi. Untuk menentukan jumlah sampel menurut Hair et al., (2014) sebaiknya ukuran sampel harus 100 atau lebih besar. Dengan aturan umum, yang berlaku 5 (lima) kali lebih besar dari jumlah item pertanyaan yang akan dianalisis, dengan ukuran sampel yang lebih dapat diterima akan memiliki rasio 10:1. Dalam penelitian ini memiliki 20 pertanyaan yang akan dikalikan dengan 5 yakni 100 responden.

\subsection{Jenis dan Sumber Data}

Dalam penelitian ini jenis penelitian sesuai dengan masalah yang diteliti, maka yang digunakan adalah penelitian kuantitatif dengan jenis penelitian asosiatif kausal. Menurut Sugiyono (2016) Penelitian asosiatif kausal adalah hubungan yang bersifat sebab akibat. jadi terdapat variabel bebas (variabel yang mempengaruhi) dan variable terikat (di pengaruhi) dan peneliti ingin mencari jawaban dengan menguji ada atau tidaknya pengaruh antara variabel bebas dan variabel terikat. Dalam hal ini variable bebas (variabel yang mempengaruhi) adalah $\mathrm{X}$ yaitu peranan promosi sosial media instagram dan variabel terikat (dipengaruhi) adalah Y yaitu keputusan pembelian konsumen. Penelitian kuantitatif merupakan suatu proses menemukan pengetahuan yang menggunakan data berupa angka sebagai alat menganalisis keterangan mengenai apa yang ingin diketahui (Ferdinand, 2014: 229). Penelitian ini dilakukan dengan pengumpulan data dengan menggunakan kuesioner yang disebarkan kepada sekelompok orang yang disebut responden. Dan kemudian respon yang diberikan memungkinkan peneliti untuk menarik kesimpulan mengenai keseluruhan kategori orang-orang yang diwakili oleh responden.

\subsection{Hipotesis Penelitian}

Berdasarkan teori dan juga hasil dari beberapa penelitian sebelumnya, hipotesis penelitian ini adalah :

Ha1: Peranan promosi media sosial berpengaruh terhadap keputusan pembelian konsumen di ban ban tea Emporium Pluit Mall.

Ho1: Peranan promosi media sosial tidak berpengaruh terhadap keputusan pembelian konsumen di ban ban tea Emporium Pluit Mall.

\subsection{Teknik Analisis Data}

Teknik analisis data statistik yang digunakan adalah regresi linier sederhana. Untuk mempermudah perhitungan, peneliti menggunakan alat bantu SPSS V24.0. Uji statistik yang dilakukan dalam penelitian ini, meliputi: Uji Instrumen Penelitian yaitu menggunakan uji validitas dan uji reliabilitas , Uji Asumsi Klasik untuk menguji kelayakan model regresi menggunakan uji normalitas, uji Heteroskedastisitas yang menguji bagaimana jenis dari data yang didapatkan, bersifat homogen atau heterogen, dan uji linieritas dilakukan untuk mengetahui model yang digunakan apakah menggunakan model linier atau tidak. Uji Hipotesis dalam penelitian ini terdiri dari uji regresi sederhana, Uji T, uji koefisien korelasi (R) \& koefisien determinasi $\left(\mathrm{R}^{2}\right)$.

\section{Hasil Dan Pembahasan \\ 3.1. Gambaran Umum Responden}

Penyebaran kuesioner untuk mengetahui Pengaruh Peranan Promosi Media Sosial Instagram (banban.tea) Terhadap Keputusan Pembelian Konsumen di ban ban tea Emporium Pluit mall. Dimana sosiodemografi karakteristik setiap responden juga ikut di data yang berjumlah 100 responden Data yang didapat kemudian diolah oleh peneliti dengan menggunakan program SPSS versi 24

Tabel 1. Karakteristik Responden

\begin{tabular}{|c|c|c|}
\hline Jenis Kelamin & $\begin{array}{l}\text { Respond } \\
\text { en }\end{array}$ & $(\%)$ \\
\hline Laki-Laki & 42 & $42 \%$ \\
\hline Perempuan & 58 & $58 \%$ \\
\hline Total & 100 & $100 \%$ \\
\hline
\end{tabular}

\begin{tabular}{lrr}
\hline Umur & & \\
\hline Dibawah 20 Tahun & 8 & $8 \%$ \\
\hline 21-25 Tahun & 85 & $85 \%$ \\
\hline 26-30 Tahun & 7 & $7 \%$ \\
\hline Diatas 30 Tahun & 0 & $0 \%$ \\
\hline Total & 100 & $100 \%$ \\
\hline
\end{tabular}

Tempat Tinggal 


\begin{tabular}{lrr} 
Jakarta Utara & 41 & $41 \%$ \\
\hline Jakarta Barat & 40 & $40 \%$ \\
\hline Jakarta Timur & 5 & $5 \%$ \\
\hline Jakarta Selatan & 4 & $4 \%$ \\
\hline Jakarta Pusat & 10 & $10 \%$ \\
\hline Total & 100 & $100 \%$ \\
\hline
\end{tabular}

\begin{tabular}{lrr}
\hline Pekerjaan & & \\
\hline Pelajar & 2 & $2 \%$ \\
\hline Mahasiswa/i & 76 & $76 \%$ \\
\hline Wiraswasta & 6 & $6 \%$ \\
\hline Karyawan & 16 & $16 \%$ \\
\hline Total & 100 & $100 \%$ \\
\hline
\end{tabular}

Sumber: (Hasil olahan data oleh penulis)

Berdasarkan tabel diatas dan diagram dibawah berdasarkan Jenis Kelamin, dapat dilihat bahwa total responden yaitu sebanyak 100 responden dengan jumlah responden Laki-Laki sebanyak 42 responden (42\%), sedangkan responden Perempuan sebanyak 58 responden (58\%).Jadi dapat disimpulkan bahwa mayoritas responden nya adalah Perempuan yaitu sebanyak 58 responden $(58 \%)$.

Berdasarkan tabel diatas dan diagram di bawah berdasarkan Umur, dapat dilihat bahwa total responden yaitu sebanyak 100 responden dengan jumlah responden dengan umur dibawah 20 Tahun sebanyak 8 responden $(8 \%)$ kemudian responden dengan umur 21-25 Tahun sebanyak 85 responden (85\%) kemudian responden dengan umur 26-30 Tahun sebanyak 7 responden $(7 \%)$ dan responden dengan umur diatas 30 Tahun sebesar 0 . Jadi dapat disimpulkan mayoritas responden berumur di atas 21-25 tahun sebanyak 85 responden (85\%).
Berdasarkan tabel diatas dan diagram dibawah berdasarkan Tempat Tinggal, dapat dilihat bahwa total responden yaitu sebanyak 100 responden dengan jumlah responden yang bertempat tinggal di Jakarta Utara sebanyak 41 responden $(41 \%)$ kemudian responden yang bertempat tinggal di Jakarta Barat sebanyak 40 responden $(40 \%)$ kemudian responden yang bertempat tinggal di Jakarta Timur sebanyak 5 responden $(5 \%)$ kemudian responden yang bertempat tinggal di Jakarta Selatan sebanyak 4 responden (4\%) dan responden yang bertempat tinggal di Jakarta Pusat sebanyak 10 responden (10\%). Jadi dapat disimpulkan mayoritas responden bertempat tinggal di Jakarta Utara yaitu sebanyak 41 responden (41\%).

Berdasarkan tabel diatas dan diagram dibawah berdasarkan Pekerjaan, dapat dilihat bahwa total responden yaitu sebanyak 100 responden dengan jumlah responden dengan pekerjaan sebagai Pelajar sebanyak 2 responden (2\%) kemudian responden dengan pekerjaan Mahasiswa/I sebanyak 76 responden (76\%) kemudian responden dengan pekerjaan wiraswasta sebanyak 6 responden $(6 \%)$ dan responden dengan pekerjaan karyawan sebanyak 16 responden (16\%). Jadi dapat disimpulkan bahwa mayoritas responden adalah Mahasiswa/i yaitu sebanyak 76 responden $(76 \%)$.

\subsection{Uji Instrument}

Hasil uji validitas, menunjukan nilai Corrected Item-Total Correlation memiliki nilai koefisien positif dan lebih besar dari pada 0,3 , sehingga seluruh butir pernyataan yang digunakan pada kuesioner penelitian ini adalah valid. Hasil nilai Cronbach's Alpha seluruh variabel penelitian adalah lebih besar dari 0,6 sehingga layak atau reliabel digunakan untuk menjadi alat ukur instrumen kuesioner dalam penelitian ini.

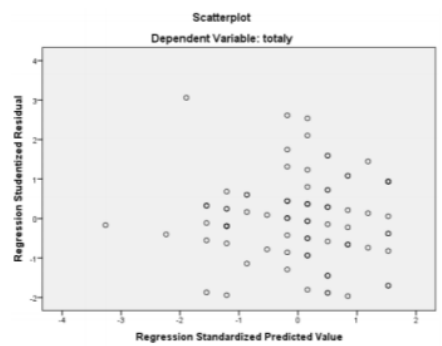

Gambar 4. Uji Heteroskedastisitas

Sumber: (Hasil olahan data SPSS) 
Berdasarkan gambar 4., maka dapat dilihat bahwa titik - titik data menyebar di atas dan di bawah atau di sekitar angka 0 , titik - titik data tidak membentuk pola bergelombang melebar kemudian menyempit dan melebar kembali. Sehingga dapat disimpulkan bahwa data tidak terjadi heteroskedastisitas.

Tabel 2. Uji Regresi Sederhana

\begin{tabular}{|c|c|c|c|c|c|c|}
\hline \multicolumn{7}{|c|}{ Coefficients ${ }^{a}$} \\
\hline \multirow[b]{2}{*}{ Model } & & \multicolumn{2}{|c|}{ Unstandardized Coefficients } & \multirow{2}{*}{$\begin{array}{l}\text { Standardized } \\
\text { Coefficients } \\
\text { Beta }\end{array}$} & \multirow[b]{2}{*}{$t$} & \multirow[b]{2}{*}{ Sig. } \\
\hline & & $\mathrm{B}$ & Std. Error & & & \\
\hline 1 & (Constant) & 8.140 & 2.205 & & 3.691 & .000 \\
\hline & totalx & 1.179 & .080 & .831 & 14.801 & .000 \\
\hline
\end{tabular}

a. Dependent Variable: totaly

Sumber: (Hasil olahan data SPSS)

Berdasarkan hasil olahan regresi dengan menggunakan program komputerisasi SPSS versi 24.0, maka dapat disajikan persamaan regresi yaitu sebagai berikut:

$$
Y=8.140+1.179 X
$$

Dari persamaan regresi tersebut, maka dapat diberikan penjelasan sebagai berikut:
1. Konstanta yang dihasilkan sebesar 8.140 yang berarti bahwa nilai konsisten variabel Keputusan Pembelian adalah 8.140

2. Koefisien regresi $\mathrm{X}$ yaitu Promosi sebesar 1.179, maka nilai partisipasi bertambah sebesar 1.179. Maka dari itu koefisien regresi ini bernilai positif dan dapat dikatakan bahwa pengaruh variabel $\mathrm{X}$ terhadap variabel $\mathrm{Y}$ positif.

Tabel 3. Uji F

ANOVA $^{\mathrm{a}}$

\begin{tabular}{ll|r|r|r|r|r} 
Model & Sum of Squares & df & Mean Square & \multicolumn{1}{c}{ F } & \multicolumn{1}{c}{ Sig. } \\
\hline 1 & Regression & 1174.580 & 1 & 1174.580 & 219.080 & $.000^{\text {b }}$ \\
\cline { 2 - 7 } & Residual & 525.420 & 98 & 5.361 & & \\
\cline { 2 - 7 } & Total & 1700.000 & 99 & & & \\
\hline
\end{tabular}

a. Dependent Variable: totaly

b. Predictors: (Constant), totalx

Sumber: (Hasil olahan data SPSS)

Berdasarkan dari tabel diatas hasil pengolahan data dengan menggunakan program SPSS versi 24, dimensi pada variabel $\mathrm{X}$ yaitu Promosi terhadap variabel $\mathrm{Y}$ yaitu
Keputusan Pembelian di dapatkan uji F hitung sebesar 219.080 > F tabel 3,95 dengan tingkat signifikasi $0,000<0,05$.

Tabel 4. Uji R 


\begin{tabular}{|c|c|c|c|c|}
\hline \multicolumn{5}{|c|}{ Model Summary } \\
\hline Model & $\mathrm{R}$ & R Square & $\begin{array}{l}\text { Adjusted R } \\
\text { Square }\end{array}$ & $\begin{array}{c}\text { Std. Error of the } \\
\text { Estimate }\end{array}$ \\
\hline 1 & $.831^{\mathrm{a}}$ & .691 & .688 & 2.315 \\
\hline
\end{tabular}

Sumber: (Hasil olahan data SPSS)

Berdasarkan tabel diatas, menjelaskan bahwa besarnya nilai korelasi / hubungan (R) yaitu sebesar 0,691. Dari hasil tersebut diperoleh koefisien determinasi (R Square) sebesar 0,691 yang berarti bahwa pengaruh variabel $X$ atau bebas (Promosi) terhadap variabel $\mathrm{Y}$ atau terikat (Keputusan Pembelian) adalah sebesar $69,1 \%$. Sedangkan sisanya sebesar 30,9\% dipengaruhi oleh variabel lain yang peneliti tidak masukkan dan tidak diteliti dalam penelitian ini.

\section{Simpulan}

Berdasarkan hasil penelitian yang membahas mengenai pengaruh peranan promosi media sosial instagram (banban.tea) terhadap keputusan pembelian dengan melakukan pengumpulan data dengan penyebaran kuesioner kepada 100 responden yang pernah melakukan pembelian di ban ban tea emporium pluit mall. Maka dapat ditarik kesimpulan sebagai berikut:

1. Ban ban tea hanya menggunakan media sosial instagram sebagai sarana utama promosi untuk menarik konsumen sehingga terjadinya keputusan pembelian.

2. Berdasarkan profil responden dapat disimpulkan bahwa mayoritas yang mengikuti akun instagram(banban.tea) adalah perempuan dengan umur kebanyakan 21-25 tahun dengan bekerja sebagai mahasiswa/i dengan mayoritas responden bertempat tinggal di jakarta utara dengan penghasilan perbulan kebanyakan sebesar 1.000.000-3.000.000 yang dimana mayoritas respondennya tertarik dengan ban ban tea setelah melihat iklan/promosi di media sosial instagram (banban.tea).

3. Hasil dari penelitian ini juga menunjukan bahwa $69,1 \%$ dari variabel $\mathrm{X}$ (Promosi) berpengaruh terhadap variabel $\mathrm{Y}$ (Keputusan Pembelian), sedangkan 30,9\% dipengaruhi oleh variabel lain yang peneliti tidak masukkan dan tidak diteliti dalam penelitian ini.

4. Berdasarkan hasil olah data dengan menggunakan uji $\mathrm{T}$ yaitu dapat disimpulkan bahwa variabel $\mathrm{X}$ (Promosi) berpengaruh signifikan terhadap variabel Y (Keputusan Pembelian), karena nilai $\mathrm{t}$ hitung sebesar $14.801>t$ tabel 1,984.

5. Berdasarkan hasil olah data dengan menggunakan uji $\mathrm{F}$, dimensi yang ada pada variabel X (indikator Promosi) yaitu: menginformasikan, membujuk dan mengingatkan berpengaruh signifikan terhadap keputusan pembelian di ban ban tea Emporium Pluit Mall

\section{Daftar Pustaka}

Arikunto, S. (2016). Prosedur Penelitian Suatu Pendekatan Praktik. Jakarta: Rineka Cipta.

Fandy Tjiptono, Ph.D. 2015. Strategi Pemasaran, Edisi 4, Penerbit Andi, Yogyakarta.

Ferdinand, Augusty. 2014. Metode Penelitian Manajemen. BP Universitas Diponegoro. Semarang

Hair, Jr et.al. (2010). Multivariate Data Analysis (7th Ed). United States: Pearson

Andres Kaplan \& Michael HaenLein, 2010.User Of The World, Unite! The Challenges and Opportunities of Social Media, Business Horizons.

Kotler, Philip \& Amstrong, Gary. 2014. Prinsip-prinsip Manajemen. Edisi 14. Jilid 1. Jakarta: Erlangga. 
Sugiyono. (2016). Metode Penelitian Kuantitatif, Kualitatif dan R\&D. Bandung: PT Alfabet.

Sugiyono. (2017). Metodologi penelitian kuantitatif, kualitatif, dan R\&D. Bandung: Alfabeta.

Asosiasi Penyelenggara Jasa Internet Indonesia: www.apjii.or.id
Napoleoncat:

https://napoleoncat.com/stats/instagra m-users-in-indonesia/2020/06

Instagram ban ban tea: https://www.instagram.com/banban .tea/?hl=en 